\title{
Havana Syndrome Possible Cause
}

\author{
Paul TE Cusack* \\ 23 Park Ave, Saint John, NB, E2J 1R2, Canada \\ *Corresponding author: Paul TE Cusack, 23 Park Ave, Saint John, NB, E2J 1R2, Canada
}

\begin{tabular}{|c|c|}
\hline ARTICLE INFO & ABSTRACT \\
\hline Received: May 27, 2021 & \multirow{3}{*}{$\begin{array}{l}\text { The Havana Syndrome has gained notice after personnel at the US White House } \\
\text { were attacked with vertigo. A cause suggested was that it could be microwave attacks } \\
\text { from an enemy of the US. In this paper, we consider sound waves and infrared waves in } \\
\text { combination with the function of the human mind, the golden mean parabola. We see } \\
\text { that the cause could be either a high-pitched sound or infrared waves aimed at the brain } \\
\text { of a genius. It also could be caused by an infrared thermometer for health monitoring. It } \\
\text { is possible that the Havana Syndrome could be a national security threat to Canada and } \\
\text { the USA. }\end{array}$} \\
\hline Published: 㓞 June 10, 2021 & \\
\hline $\begin{array}{l}\text { ation: Paul TE Cusack. Havana Syn- } \\
\text { me Possible Cause. Biomed J Sci \& Tech } \\
\text { 36(3)-2021. BJSTR. MS.ID.005847. }\end{array}$ & \\
\hline
\end{tabular}

Keywords: Havana Syndrome; Infrared; High Frequency Sound Waves; ACT* Model; AT Math

\section{Introduction}

Last weekend (May 26 $6^{\text {th }}, 2021$ ), I experienced extremely bad vertigo. I was put to the kitchen floor on all fours as I walked out of my bedroom. I needed an escort to get back to the bed to lie down. A roommate aged 30, had extremely bad vertigo as well that had lasting impact. My immediate thoughts were of the microwave attacks upon US NSL personnel at the white house recently which was in the news. But why would they attack me? And how would they do it indoors? Why would they attack my roommate?

Armed with the knowledge of the human function, viz the golden mean parabola, I set to do some calculations. I considered soundwaves; infrared waves; and microwaves. The calculations are as follows.

Human hearing frequency range $=12 \mathrm{~Hz}-28 \mathrm{kHz}$, but most common is $20-20,000 \mathrm{~Hz}$

$$
\begin{aligned}
& E=\hbar v \\
& =6.626(20 \mathrm{kHz}) \\
& =132.520 \mathrm{~kJ} \\
& E=1 / t \\
& t=1 / E=1 / 132.520=7.546 \text { microseconds }
\end{aligned}
$$

$$
\begin{aligned}
& t^{2}-t-1=E \\
& 7.546^{2}-7.546-1=48.396 \sim 48.4 \\
& 1 / 48.396=0.02066 \\
& =20,663 \mathrm{~Hz}
\end{aligned}
$$

This would be a grating sound at such a high frequency. It could cause a headache and hearing loss. The function of the mind was provided in a previous paper [1] as the GMP: $t^{2}-t-1=0$. If we use that function for the mind, the ACT* model of the mind has working memory as [2].

$$
t=0.888 E=-1.099 \sim-1.1
$$

Memory stored in nerve cells could be destroyed from a high pitch (Figure).

$$
\begin{aligned}
& E=\hbar v \\
& -1.1=6.626 v \\
& v=-1.660 \sim-1 / 602 \\
& \text { Circ }=\text { Are } \\
& 2 \pi R=\pi R^{2} \\
& 2=\mathrm{R}
\end{aligned}
$$




$$
2 \pi(2)=4 \pi=1.2566
$$

$E=\hbar v$

$1.2566=6.626 v$

$v=0.1896=t$

$t^{2}-t-1=E$

$0.1896^{2}-0.1896-1=-1.154=-1 / 0.866=-1 / \sin 60^{\circ}=E$

$s=E \times t=|E||t| \sin \theta$

Let $\mathrm{s}=\mathrm{t}$

$E=1 / \sin \theta w h e r e \theta=\pi / 3=1.0472$

Genius Brain Waves $=80-82 \mathrm{~Hz}$

Infrared freq $=430 \mathrm{tHz}$

$81 \mathrm{~Hz} / 430 \mathrm{THz}=0.18837 \mathrm{cf} .18896$ above

$t^{2}-t-1=E$

$(0.18837)^{2}-(0.18837)-1=-1.15288=E$

$=1 / 0.867=1 / t$

$E=1 / \sin 60^{\circ}$

$s=E \times t=|E||t| \sin \theta$
Let $\mathrm{s}=\mathrm{t}$

$E=1 / \sin \theta$

Resonance of the human body produces infrasonic waves due to heartbeats; respiratory movements; blood flow and other processes.

Heart x Brain x Blood circulation

$1 \mathrm{~Hz} \times 10 \mathrm{~Hz} \times 0.05 \mathrm{~Hz}=0.5 \mathrm{~Hz}=$ frequency $=\mathrm{t}$

$$
\begin{gathered}
t=1 / 2 \\
t^{2}-t-1=E
\end{gathered}
$$

$(0.5)^{2}-0.5-1=E$

$E=-1.25$

$s=E t \sin \theta$

$=(-1.25)(0.5)(0.866)$

$=-0.54125$

$s=t$

$t^{2}-t-1=E$

$(-0.54125)-(-0.54125)-1$

$=-1.658 \sim 1 / 603$

$\sin -1(t)=\sin -1(-0.54125)=-32.768^{\circ}=0.5719=1 \mathrm{rad} / 10=1 /$ Brain Freq . Brain Freq $=1 /-0.54125=-1.847=E$

$1 / E=t=4.261 C f . t=430 \mathrm{THz} \Rightarrow$ Infrared Waves

\section{ACT* Model}

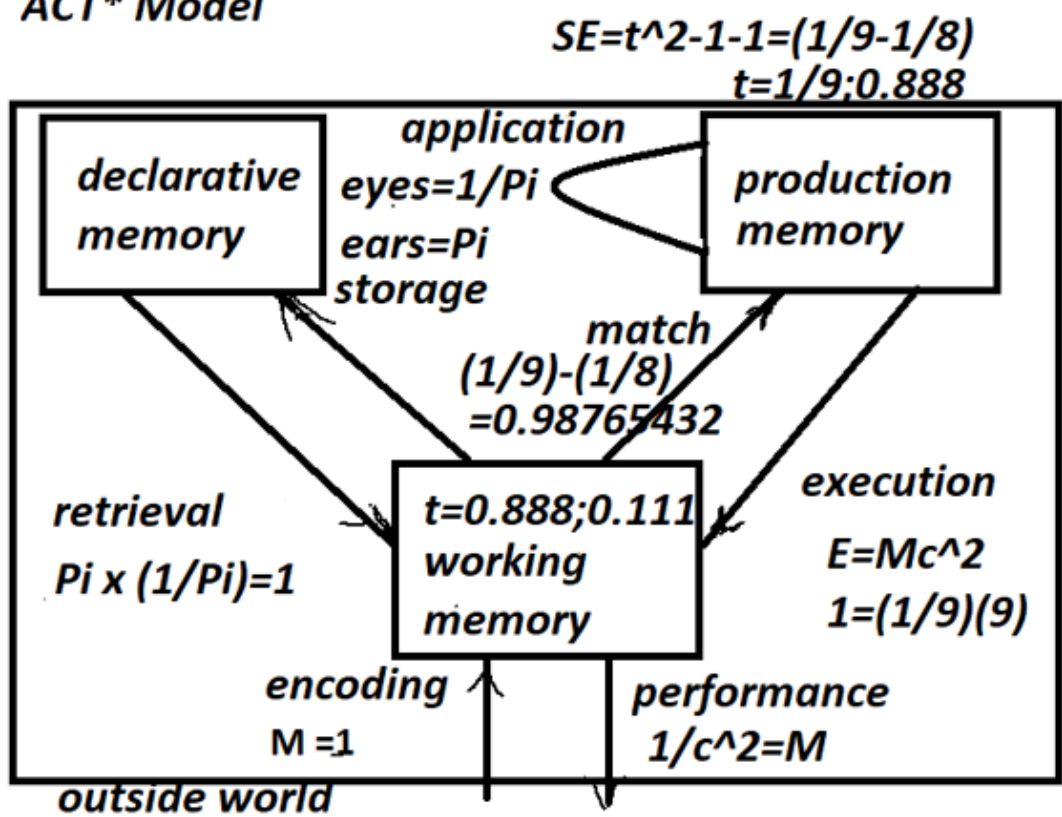

Figure 1: Human Consciousness. 


\section{Conclusion}

Our calculations point to a combination of sound waves and infrared waves. Since our temperatures are being measured by infrared thermometers, I suspect the attacks of vertigo etc. were from infrared rays from the thermometer. In the attacks at the White House and Havana, they are likely a combination of high frequency sound and infrared triangulation, or stereo sound targeted to a heat signal. This could be a serious national security problem if an enemy could attack geniuses.

\section{ISSN: 2574-1241}

DOI: $10.26717 /$ BJSTR.2021.36.005847

Paul TE Cusack. Biomed J Sci \& Tech Res

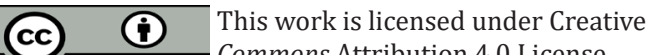

Submission Link: https://biomedres.us/submit-manuscript.php

\section{Conflict of Interest}

The authors declare that there is no conflict of interest.

\section{References}

1) Paul TE Cusack (2020) The Human \& Universal Functions. Curr Tre Biosta \& Biometr 3(2).

2) Phys.org webpage.

$\begin{array}{ll}\text { BIOMEDICAL } & \text { Assets of Publishing with us } \\ \text { RESEARCHES } & \text { - Global archiving of articles } \\ \text { - Immediate, unrestricted online access }\end{array}$

